ISSN 2078-6441. Вісник Львівського університету. Серія географічна. 2013. Випуск 44. С. 302-308. Visnyk of the Lviv University. Series Geography. 2013. Issue 44. P. 302-308.

631.4

\author{
олодимир дзій \\ хідноєвропейський н ціон льний університет імені есі кр їнки, \\ просп. олі, 13, 43025, м. уцьк, кр їн
}

р нулометричний скл д грунтів визн ч $є$ зн чну ч стину водно-фізичних вл стивостей грунтової м си. одноч с від нього з леж ть екологічні функції т морфологічн п м'ять грунтів у р зі дослідження їхньої генези, еволюції т використ ння. озглянуто основні методи гр нулометричного н лізу й опис но суч сні методи, які щор з більш з стосовуються для дослідження в грунтозн встві, геології, хімічній, ф рм цевтичній т інших г лузях промисловості.

лючові слов : гр нулометричний скл д грунту, седиментогр ф, л зерн дифр кція.

p нулометричний скл д грунтів перев жно усп дков ний від грунтотворних порід т м ло змінюється в процесі грунтоутворення. собливості скл ду м теринських порід визн ч ють мінер льний т зн чною мірою вплив ють н хімічний скл д грунту; будов т структур порід зумовлюють мех нічні, водно-фізичні й інші вл стивості грунтів. л мки щільних порід і мінер лів, які утворюють тверду ф зу грунтів, розрізняють не тільки з типом крист лічної гр тки і хімічним скл дом; вони утворюють суміш мінер льних ч сток різного розміру, які н зив ють мех нічними елемент ми [10]. ерев ж ння ч стинок того чи іншого розміру в грунтових пород $\mathrm{x}$ i грунт х визн ч $є$ зн чну ч стину фізичних вл стивостей грунтової м си (пористість, повітро- т водопроникність, вологоємність, гігроскопічність тощо). р нулометричний скл д відобр ж є всі основні грунтові процеси, є одним із фунд ментів родючості грунтів. д ними гр нулометричного н лізу оцінюють потенційну зд тність грунтів до ер ції. одноч с гр нулометричний скл д визн ч є екологічні функції грунтів, т кі як поширення рослин, освоєння грунту кореневою системою, з безпечення рослин водою т елемент ми живлення [9].

цьому р зі для кожної з рослин існує певний оптимум, який треб вр ховув ти, розробляючи з ходи р ціон льного використ ння земель [16]. ні гр нулометричного н лізу використовують для бонітетної оцінки грунтів, у розробці проектів осушув льних і зрошув льних систем. лежно від гр нулометричного скл ду грунтів змінюються умови обробітку, терміни польових робіт, норми внесення добрив т хімічних меліор нтів, розміщення сільськогоспод рських культур тощо.

ивчення елементів скл дної грунтової орг ніз ції, які містять в жливу інформ цію про процеси і чинники грунтоутворення, дослідження генези, еволюції т використ ння грунтів від м кро-, субмікром сшт бів до н ном сшт бів треб вв ж ти орг ніз ційноієр рхічним вивченням морфологічної п м'яті грунтів. од льше вивчення носіїв грунтової п м'яті передб ч $є$ н літичне дослідження елементного скл ду т вл стивостей твердої ф зи усім комплексом методів, вл стивих грунтозн вству, геохімії т мінер логії, щодо з'ясув ння різних видів п м'яті грунтів, одним з яких є гр нулометричн п м'ять [13].

(C) дзій ., 2013 
роте сьогодні є дві основні проблеми - з стосув ння н йоб'єктивніших методів дослідження, інтерпрет ції результ тів т кл сифік ції гр нулометричного скл ду грунтів.

p метри, що х р ктеризують гр нулометричний скл д грунтів, д ють змогу кл сифікув ти грунти і грунтотворні породи. з розвитком суч сних дист нційних методів дослідження т їхнього щор з ширшого з стосув ння під ч с дослідження фізичних вл стивостей грунтів пост є пит ння оптим льного вибору методу н лізу гр нулометричного скл ду, підходів до інтерпрет ції результ тів н лізу т кл сифік ції. і проблеми н йповніше розкрив є . еін, який з зн ч є, що суттєве різном ніття методів, кл сифік цій, прил дів, які використовують різні фізичні принципи (седиментометрія, л зерн дифр ктометрія), зумовлює вр хув ння особливостей методів і кл сифік цій, з кономірностей кількісного переведення д них з однієї кл сифік ції в іншу [2, 18]. . ктіонов про н лізув л історію розвитку різних кл сифік цій гр нулометричного скл ду грунтів і способів д пт ції між ними. собливу ув гу вон кцентув л н можливості переходу від результ тів н лізу 3 методикою чинського до кл сифік ції гр нулометричного скл ду USDA/FAO [4]. собливості дослідження гр нулометричного скл ду грунтів метод ми л зерної дифр ктометрії висвітлено в публік ціях . лохін , . еін, . іл новського, . лужського $[1,2]$. ироке з стосув ння ці методи отрим ли у літологічних дослідженнях т інженерно-геологічних вишукув ннях, про що з зн ч ють . т дніченко, . одоб , - итропольський т ін. [7, 11, 12]. кож методи т методики визн чення гр нулометричних фр кцій використовують для дослідження і розробки технологічних схем екстр гув ння в хімічній, ф рм цевтичній т інших г лузях $[8,15]$. ні гр нулометричного н лізу широко використовують під ч с вивчення мікроморфологічних особливостей грунтів із з стосув нням фотогр мметричних методів цифрової обробки p строво-електронно-мікроскопічних зобр жень (знімків), т кож у р зі ідентифік ції сиплексу ф кторів еродов ності грунту, отрим них 3 допомогою рентгенівського дифр ктометр [5,6].

ші мет і з вд ння - висвітлити суч сні проблеми дослідження гр нулометричного скл ду грунтів т підходи до інтерпрет ції д них н лізу; про н лізув ти методи гр нулометричного н лізу, які прийняті в н укових дослідженнях у г лузі грунтозн вств т інженерно-грунтозн вчих вишукув нь; висвітлити особливості з стосув ння л зерного седиментогр ф для визн чення розмірів елемент рних грунтових ч сток.

р нулометричний скл д грунтів приблизно н $90 \%$ предст влений елемент рними грунтовими ч сточк ми ( ) мінер льної природи. цьому р зі можуть м ти будь-яку геометричну форму: куля, куб, призм тощо. мовно їхню форму прийм ють 3 кулеподібну, вр ховуючи т к зв ний ефективний ді метр. ідт к гр нулометричний скл д - це відносний вміст у грунті різного ді метр т хімічного скл ду. ого вир ж ють, передусім, у вигляді м сових відсотків фр кцій гр нулометричних ч сток різного ді метр .

сі грунтові вишукув ння проводять для вирішення прикл дних з вд нь, вони обов'язково супроводжуються визн ченням гр нулометричного скл ду. польовому морфологічному описі використовують візу льні методи, в л бор торних умов х точно визн ч ють гр нулометричний скл д досліджув них грунтів прийнятими метод ми н лізу. польових умов х гр нулометричний скл д визн ч ють “сухим" і “мокрим" метод ми. итовий метод гр нулометричного н лізу з стосовують для визн чення к м’янистої ч стини грунтів різного гр нулометричного скл ду, т кож в 
н лізі пісків [3]. ля більшої ефективності просіюв ння н бір сит вст новлюють у спеці льний прил д - рот п.

6 г то методів визн чення гр нулометричного скл ду, які поділяють н дві групи: н ліз у проточній воді (методи ебеля, ене, опецького т ін.); н лізу в стоячій воді (методи сборн, нопп, ппі ні, ільямс, б нін, ттерберг, лушков , обінсон, іл тов, чинського, олгов тощо).

дним із н йпоширеніших методів є метод піпетки, який грунтується н вр хув нні швидкості осід ння ч сток різного розміру в рідкому середовищі т відборі проб із суспензії з глибини [10]. р нулометричний н ліз скл д ється з двох основних ет пів: дисперг ції грунтової м си т н лізу вмісту ч сток різного розміру. ільки після ет пу мех нічного розділення визн ч ють вміст ч сток різного розміру - визн ч ють гр нулометричний скл д. основу розр хунків, які виконують 3 гідр влічних способів н лізу, узято формулу токс - швидкість ос дження ч стинок сферичної форми з лежить від р діус ч стинок, питомої в ги ч стинок, питомої в ги води, прискорення сили тяжіння і в'язкості води.

окрему групу виділяють методи, які грунтуються н дослідженні фізичних вл стивостей : л зерн дифр кція (ос дження), кондуктометричний метод (лічильник оултер ), оптичні методи ( н ліз зобр жень).

ентген-седимент ційний метод гр нулометричного н лізу грунтується н принципі вимірюв ння густини седиментув льної дисперсії з поглинутими рентгенівськими променями з втом тичною реєстр цією результ тів у вигляді інтегр льної кривої м с-розподілу в ді п зоні ч сток ді метром від 100 мкм (0,1 мм) і менше. ей метод добре пок зує неперервну криву гр нулометричного скл ду т виділяє особливості досліджув ного зр зк ; розділення проби з допомогою ультр звуку до оптим льного виходу тонких фр кцій, що з безпечує цілісність гр нулометричних елементів; серія послідовних н лізів д є змогу оцінити міцність мікроструктури грунту [17].

допомогою прил ду Sedigraph 5100 (Micromeritics Instrument Corporation, Norcross, GA, USA) вимірюють швидкість ос дження ч стинок, визн ч ючи рентгенівським випроміненням мутність н різних рівнях стовпчик зр зК . ні розподілу н водять у відсотк х щодо м си.

ост нні 10-15 років інтенсивно розвив ється метод л зерної дифр кції, який з стосовують для визн чення розподілу ч сток з розміром і в якому використовують фізичний принцип флукт ції електром гнітних хвиль. вітло п р лельного л зерного променя з зн є з ломлення твердоф зовими ч стк ми і відхиляється н фіксов ні кути, які з леж ть від ді метрів і оптичних вл стивостей ч сток. 3 г льної сукупності кожен індивіду льний розмір ч сток лок лізує певний кут розсіюв ння, розшифрув ння дифр кційної к ртинки д $є$ змогу розр хув ти відсотковий вміст ч сток різного розміру. ведені в одній точці лінзи фокусують розсіяне світло в кільці н центр льній п нелі, де детектор вимірює розподіл світлової енергії (спектр ур'є). озподіл ч сток 3 розмір ми обчислюють відповідно до теорії $p$ унгофер 3 єдиною розр хунковою процедурою. ля визн чення гр нулометричного скл ду грунтів л зерним дифр ктометричним (оптичним) методом використовують прил ди різних конструкцій. лежно від моделі прил ду проб може бути підд н вимірюв нню н віть у сухому ст ні. к носій у цьому вип дку використовують струмінь повітря, що рух ється зі швидкістю, більшою від швидкості звуку. е відкрив є нові можливості для отрим ння дод ткових відомостей про ст н твердої ф зи грунту. $р$ зі визн чення гр нулометричного скл ду грунтів цим методом використовують універс льний л зерний дифр кційний н ліз - 
тор розміру ч сток SALD-201V фірми SHIMADZU ( понія), л зерний седиментогр ф Mastersizer 2000 (Malvern Instruments, UK). його допомогою можн визн ч ти вміст ч сток розміром від 350 до 0,25 мкм (від 0,35 до 0,00025 мм) [1].

езульт ти досліджень гр нулометричного н лізу зр. 2, що х р ктеризує ілюві льний горизонт (30-60 см) сірого лісового грунту, отрим ні л зерним седиментогр фом Mastersizer 2000 (Malvern Instruments, UK) (див. рисунок). ні н ведені відповідно до об'єму, м ксим льно відповід ють ре льному розподілу ч сток з фр кціями. рисунку відобр жено криву розподілу ч сток 3 розміром. ісь $x$ - розмір ч сток, мкм, вісь $y$ - відсотковий вміст (відповідно до кількості ч стинок). иференційн крив ілюструє з г льну к ртину і перев жні у цьому зр зку фр кції. окрем , м ксим льн кількість ч стоК н ді п зон розмірностей (фр кцій) 0,05-0,002 мм (50-2 мКм) т ст новить $79 \%$.

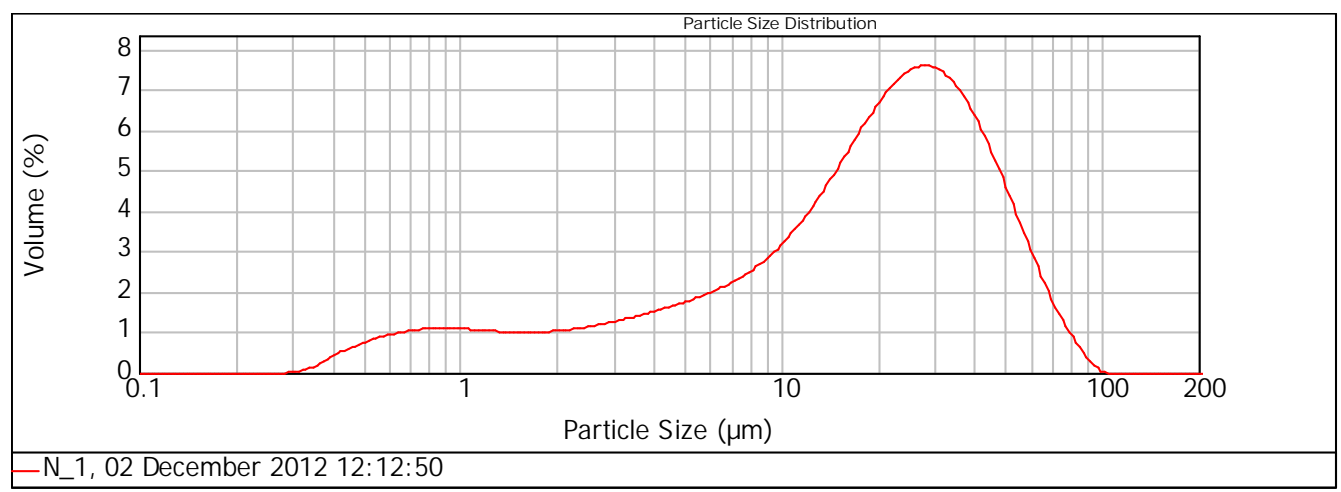

езульт т н лізу гр нулометричного скл ду зр. 2.

ондуктометричний метод. изн чення розмірів окремих ч стинок виконують 3 імпульс ми електричного струму. стинки перебув ють у з вислому ст ні в розчині електроліту і проходять через невеликий отвір. в електроди створюють електричний струм у цьому отворі. оли ч стк проходить через нього, вон з міщує вл сним об'ємом електроліт, збільшуючи опір в отворі. творен пульс ція прямо пропорційн до об'єму ч стки. н ліз пульс цій д є змогу отрим ти розподіл з вислих ч стинок з розміром. ей прил д визн ч є гр нулометричний скл д, т кож концентр цію ч сток у зр зку. имірюв ння н лічильнику охоплюють ч стки ді метром від 1,8 до 20,7 мкм [12].

“ с переміщення” ( ). иявлення ч стинок відбув ється 3 допомогою л зерного променя, що оберт ється. ромінь, сфокусов ний н невелику точку, з безпечує кругове ск нув ння призми з досліджув ним зр зком. к с мо як л зерн дифр кція, метод 3 цим принципом, є CIS-100 [12].

о оптичних ( н ліз зобр ження) н леж ть т кі методи: ст тичний н ліз зобр ження (SIA) т дин мічний н ліз зобр ження (DIA). етод SIA грунтується н прогр мному з безпеченні для дослідження морфометричних п р метрів ч сток із цифрових знімків. 
кож для н лізу ч стинок розміром до 2 мкм 3 стосовують т кі прил ди, як тр нсмісійні електронні мікроскопи (ТЕМ) т ск нув льні електронні мікроскопи (SEM), що н д ють інформ цію про розміри, форму т морфологічні особливості.

явні сьогодні методи визн чення фільтр ційних вл стивостей грунтів трудомісткі й досить трив лі з ч сом, тому особливого зн чення н були методи оцінюв ння структури порового простору т ч сток з допомогою р стрового електронного мікроскоп ( ), що д ють змогу виявляти проникність грунтів з зр зК ми м лого розміру. етод передб ч є н ліз -зобр жень спеці льно підготовлених поверхонь зр зків. ількісний н ліз структури порового простору зр зків виконують 3 допомогою п кет прикл дних прогр м STIMAN ( STIMAN), розробленого в осковському держ вному університеті імені • омоносов - сновною відмінністю цього методу є те, що він д $є$ змогу вирішити проблему одноч сного опр цюв ння кількох різном сшт бних зобр жень (до десяти). допомогою STIMAN можн отрим ти т кі х р ктеристики: розмір і форму структурних елементів, їхню орієнт цію, площу, периметр, пористість, питому поверхню тощо. пеці льн прогр м ст тистичного опр цюв ння д є змогу будув ти відповідні гістогр ми, модифіков ний в рі нт п кет - отримув ти т ку в жливу х р ктеристику, як фільтр ційний коефіцієнт грунту [6].

роте кл сичні ТЕM т SEM методики передб ч ють дуже скл дну і трудомістку процедуру підготовки зр зків (усунення гломер тів глинистих ч стинок). ове покоління мікроскопів предст влене ск нув льним мікроскопом (Scanning Probe Microscopy (SPM)), що відрізняється простотою процедури підготовки зр зК т високою роздільною зд тністю (від мікроскопічних до розмірів том ). изн чення гр нулометричного скл ду грунтується н вимірюв нні ді метр т товщини ч сток; результ ти н ведені у відсотк х щодо м си чи кількості ч сток. етод SPM є дуже потужним інструментом у дослідженні розміру ч стинок грунту н н норівні [11].

зн чені методи н лізу гр нулометричного скл ду грунтуються н певному фізичному принципі, проте є проблеми зіст влення результ тів н лізу із кл сичними метод ми визн чення розмірів елемент рних грунтових ч сток. ожен із цих методів м є особливі способи пробопідготовки. розр хункові моделі з кл дено різні форми ч сток тощо.

тже, н ліз суч сних методів визн чення гр нулометричного скл ду грунтів з свідчив перспективність ширшого їх з стосув ння в пр ктиці прикл дних грунтових досліджень. пис ні методи суттєво зменшують ч с проведення н лізу. ля зіст влення результ тів н лізу необхідно н копичув ти ф ктичний м тері л, розробляти лгоритми переходу до н ціон льної системи кл сифік ції грунтів 3 гр нулометричним скл дом. собливу ув гу н це повинні звернути члени ехнічного комітету ст нд ртиз ції “рунтозн вство” ( 142$)$, які пр цюють н д розробкою, впров дженням і д пт цією н ціон льних ст нд ртів у сфері грунтозн вств, грохімії й охорони грунтів, т кож пр цюють у н прямі системної г рмоніз ції з міжн родними т європейськими ст нд рт ми.

\section{СПИСОК ВИКОРИСТАНОЇ ЛІТЕРАТУРИ}

1. лохин . . ценк применения метод л зерной дифр ктометрии в определении гр нулометрического сост в [ екст] / . . лохин, . . улижский // естник . иология. -2009 . - № 1. - . 37-43. 
2. лохин . . $\mathrm{p}$ ктеристик гр нулометрического и грег тного сост в почв северной ч сти ре л ерневой т йги узнецкого л т у с использов нием п р метров вероятностных функций [ екст] / . . лохин, . . еин, . . ил новский // естник . иология. - 2010. - № 2 (10). - . 7-18.

3. чинский . . ех нический и микро грег тный сост в почвы, методы его изучения / . . чинский. - . : зд тельство , 1958. - 192 c.

4. ктіонов . . ро можливість з стосув ння в кр їні кл сифік ції гр нулометричного скл ду грунтів USDA/FAO [ екст] / . . ктіонов // грохімія і грунтозН вство. - 2011. - ип. 74. - . 36-46.

5. ельник . . еякі пит ння ідентифік ції моделей водної т вітрової ерозії [ екст]/ . . ельник, . . дзій, . . ендель // уч сні досягнення геодезичної н уки т виробництв . - 2013. - № 1 (25) - . 139-144.

6. ельник. . - - н ліз мікроструктури дерново-підзолистих грунтів [ екст] / . . ельник, . . дзій, . . ельник // існ. геодезії і к ртогр фії. -2010. № 5. - . 29-34.

7. итропольський . . . езульт ти досліджень донних відкл дів н геоекологічному полігоні в меж х експеримент льного відділення морського гідрофізичного інституту кр їни [ екст] / . . итропольський, . . сєдкін, . . в нов т ін. // кологічн безпек прибережної т шельфової зон т комплексне використ ння ресурсів шельфу. - 2011. - ип. 25, . 1. - . 181-191.

8. $\quad c$ суук . . інетик екстр гув ння м сел з нетр диційної рослинної сировини : втореф. дис. н здобуття н ук. ступеня к нд. техн. н ук : спец. 05.18.12 - процеси т п р ти х рчових виробництв / . . с дчук ; деськ держ. к демія х рчових технологій. - дес , 2000. - 19 с.

9. озняк . . рунтозн вство і геогр фія грунтів : підручник. двох ч стин х. . 1 / . . озняк. - ьвів: імені в н р нк, 2010. - 270 с.

10. р ктикум 3 грунтозн вств : н вч льний посібник / [ . . ихоненко, . . егтярьов, . . рохін т ін.] ; 3 ред. проф. . . ихоненк . - 6-те вид., перероб. і доп. - . : : йд н, 2009.

11. $m$ дніченко . . етодик використ ння седиментогр ф MASTERSIZER 2000 для гр нулометричного н лізу т пит ння інтерпрет ції отрим них результ тів [ екст]/ . . т дніченко, . . одоб // б. н ук. пр ць нституту геологічних н ук кр їни. $-2008 .-$ ип. 1. - .269-277.

12. $m$ дніченко . . уч сні методи визн чення гр нулометричного скл ду ос дових порід т особливості їх з стосув ння [ екст] / . . т дніченко // б. н ук. пр ць нституту геологічних н ук кр їни. - 2009. - ип. 2. - . 152-161.

13. ргульян . . мять почв: формиров ние, носители, простр нственновременное p знообр зие [ екст] / . . ргульян // мять почв. мять к к п мять биосферно-геосферно- нтропосферных вз имодействий / [под ред. . pгульян , . . орячкин ]. - . : зд-во , 2008. - . 23-57.

14. еории и методы физики почв : коллективн я моногр фия / [под ред. . . еин , . . рп чевского]. - . . “риф и ”, 2007. -616 с.

15. едорчук- ороз . . ослідження процесу екстр гув ння цільових компонентів 3 м р нтової сировини : моногр фія / . . едорчук- ороз, . . еменишин. уцьк : $\quad$, 2011. 104 с. 
16. ижевськ . . плив гр нулометричного скл ду грунту н екологічну стійкість природних систем олинської обл сті [ екст] / . . ижевськ // рирод хідного олісся т прилеглих територій : зб. н ук. пр. - 2011. - № 8. - . 22-24.

17. еин . . р нулометрический сост в почв: проблемы методов исследов ния, интерпрет ции результ тов и кл ссифик ции [ екст] / . . еин // очвоведение. - 2009. - № 3. - . 309-317.

\author{
m ття:н дійшл до ред киї̈ 08.04.2013 \\ доопр цьов н 26.04 .2013 \\ прийнят до друку 17.06.2013
}

\title{
MODERN METHODS OF GRAIN SIZE DISTRIBUTION OF SOILS
}

\author{
Volodymyr Radzii \\ Lesya Ukrainka Eastern European National University, \\ Voli Ave, 13, UA - 43025, Lutsk, Ukraine
}

Grain size distribution of soil determines much of water and physical properties of the soil mass. However, it defines ecological functions and morphological memory of soils in the study of their genesis, evolution and use. This article describes the main methods of particle size analysis and suggests the modern methods used increasingly in the research in soil science, geology, chemical, pharmaceutical and other industries.

Key words: particle size distribution of soil, sedimentograph, laser diffraction.

\section{л димир дзий}

\author{
осточноевропейский н цион льный университет имени еси кр инки, \\ просп. оли, 13, 43025, г. уцк, кр ин
}

р нулометрический сост в почв определяет зн чительную ч сть водно-физических свойств почвенной м ссы, т кже экологические функции и морфологической п мять почв в исследов ниях их генезис, эволюции и использов ния. ссмотрено основные методы гр нулометрического н лиз, опис но современные методы, которые все более применяют в почвоведении, геологии, химической, ф рм цевтической и других отр слях промышленности.

лючевые слов : гр нулометрический сост в почв, седиментогр ф, л зерн я дифр кция. 